\title{
大陆造山过程的多期演化：以西大别为例
}

\section{吴元保 ${ }^{(1)}$}

(1) 地质过程与矿产资源国家重点实验室, 中国地质大学(武汉)地球科学学院, 武汉 430074;

(2) 西北大学地质学系, 大陆动力学国家重点实验室, 西安 710069

E-mail:yuanbaowu@cug.edu.cn; cugybwu@yahoo.com

2009-03-23 收稿, 2009-05-08 接受

国家重点基础研究发展计划(编号: 2009CB825000)、国家自然科学基金(批准号: 40873043, 40821061, 90714010, 40772042)、教育部创新团 队项目(批准号: IRT0441)、教育部“111”创新引智计划(编号: B07039)和教育部新世纪优秀人才项目(编号: NCET-06-0659)资助

摘要 大陆碰撞造山带的形成和演化是汇聚板块边缘的重要特征, 其形成和演化大多经历 了复杂的过程. 以西大别为例, 利用锆石成因矿物学、 U-Pb 年龄和 $\mathrm{Hf}$ 同位素组成特点等, 结 合区域地质情况, 对造山带的多期演化提供了较为重要的制约. 结果得到, 湤湾地区洋壳的 形成时间约为 400 430 Ma, 稍晚于北秦岭与华北的碰撞时间, 可能是碰撞后扬子板块北缘 伸展作用形成的边缘盆地. 吘湾地区榴辉岩相变质作用峰期发生在约 $310 \mathrm{Ma}$ 的石炭纪, 浒 湾地区洋壳初始抬升时间约为 $270 \mathrm{Ma}$. 新县和红安地区榴辉岩的原岩时代和性质与大别-苏 鲁其他地体一致, 超高压变质作用也发生在中三叠纪, 并经历了多阶段的抬升作用过程, 应 该是大别-苏鲁造山带的西延部分. 因此, 秦岭-大别-苏鲁地区是一个典型的多阶段复合型造 山带, 其聚合过程可能持续了 $200 \mathrm{Ma}$ 以上.

大陆碰撞造山带形成和演化是汇聚板块边缘的 重要特征, 是地球动力学研究的重要领域 ${ }^{[1]}$, 但是, 对板块碰撞过程中造山带的形成和演化的具体过程 还缺乏详细的了解 ${ }^{[2 \sim 5]}$. 最新研究结果表明, 造山带 的形成和演化具有比较复杂的过程, 可能包括了多 期次的挤压和伸展作用, 挤压作用主要导致板块的 俯冲及高压-超高压变质作用, 而伸展作用则大多与 高压-超高压岩石的折返以及裂谷作用和古洋盆的形 成等有关 ${ }^{[2,6221]}$. 但是, 在造山带的多期形成和演化 过程中, 由于变质岩石大多经历了复杂的变质作用 过程, 对于造山带多期演化的性质和时间的准确确 定还存在较大的困难. 最近研究表明, 锆石微区U-Pb 定年可以确定高级变质岩石的原岩和多阶段变质年 龄, 而锆石微区Hf同位素分析可以很好地用来示踪 高级变质岩石的原岩性质 ${ }^{[22228]}$, 将锆石U-Pb定年和 $\mathrm{Hf}$ 同位素分析结合起来, 可以较好地确定同一地区
和/或不同地区形成和变质演化历史, 揭示造山带的 复杂演化过程 23227$]$.

秦岭-大别-苏鲁造山带是世界上规模最大的高 压-超高压变质带, 是国际上研究高压超高压变质作 用的经典地区 ${ }^{[1,29032]}$. 虽然对该造山带进行了 20 余 年的深入研究, 取得了丰硕的研究成果, 但是对于扬 子和华北板块缝合线的数量和位置以及它们之间高 压-超高压变质作用的时间还存在着较大的争议 ${ }^{[33 \sim 43]}$. 对该造山带西部的秦岭造山带的研究表明, 扬子和 华北板块的拼合发生在古生代 后叠加了中生代的陆内缩短作用过程 ${ }^{[41,42]}$. 对北秦 岭含金刚石和柯石英包裹体的锆石进行的微区U-Pb 定年结果显示, 北秦岭的超高压变质带可以与南阿 尔金-柴北缘的早古生代超高压变质带相连, 组成一 条沿中央造山带北部分布的加里东期超高压变质带 ${ }^{[37,43]}$; 但是, 大部分对该造山带东部的大别-苏鲁造 
山带的研究者认为, 该造山带是三叠纪扬子板块向 华北板块之下俯冲的结果 [23,24,26,30,44 57]. 西大别是研 究秦岭-大别-苏鲁造山带的重要地区之一, 该地区不 但是秦岭-大别-苏鲁造山带东部(大别-苏鲁造山带)和 西部(秦岭-桐柏造山带)的结合部分, 而且是超高压 到低压变质岩石出露的过渡带, 同时该地区受造山 后白严纪构造热事件的叠加作用不明显 ${ }^{[57 ~ 63]}$ (图 1). 近年来的研究成果揭示, 秦岭-大别-苏鲁造山带是世 界上一个非常典型的多阶段复合造山带, 经历了早 中古生代陆壳俯冲碰撞、志留纪伸展和裂谷作用及同 时代边缘洋盆的形成、以及随后大规模的三叠纪陆壳 岩石的高压-超高压变质和随后的折返作用过程.

\section{1 区域地质概况}

秦岭-大别-苏鲁造山带将扬子和华北板块分隔 在南北两边(图 1). 西大别红安地区位于该造山带的 中部, 它东部以商麻断裂为界与东大别相邻, 西部以 大悟断裂为界与桐柏造山带相隔(图 1). 从北到南它 被划分为以下 6 个变质单元: 南湾复理石带、八里畈 构造糜棱岩带、吘湾高压榴辉岩带、新县超高压变质 带、红安高压榴辉岩带以及木兰山蓝片岩-绿片岩带 [48,53,55,57,58,60]. 由于具有以下方面的特征, 该地区被 认为是研究大别-苏鲁造山带构造演化最理想的地区 [59]: (1) 榴辉岩出露面积大, 且常常保留有前进变质 的记录, 可以很好地在时间和空间上与蓝片岩和

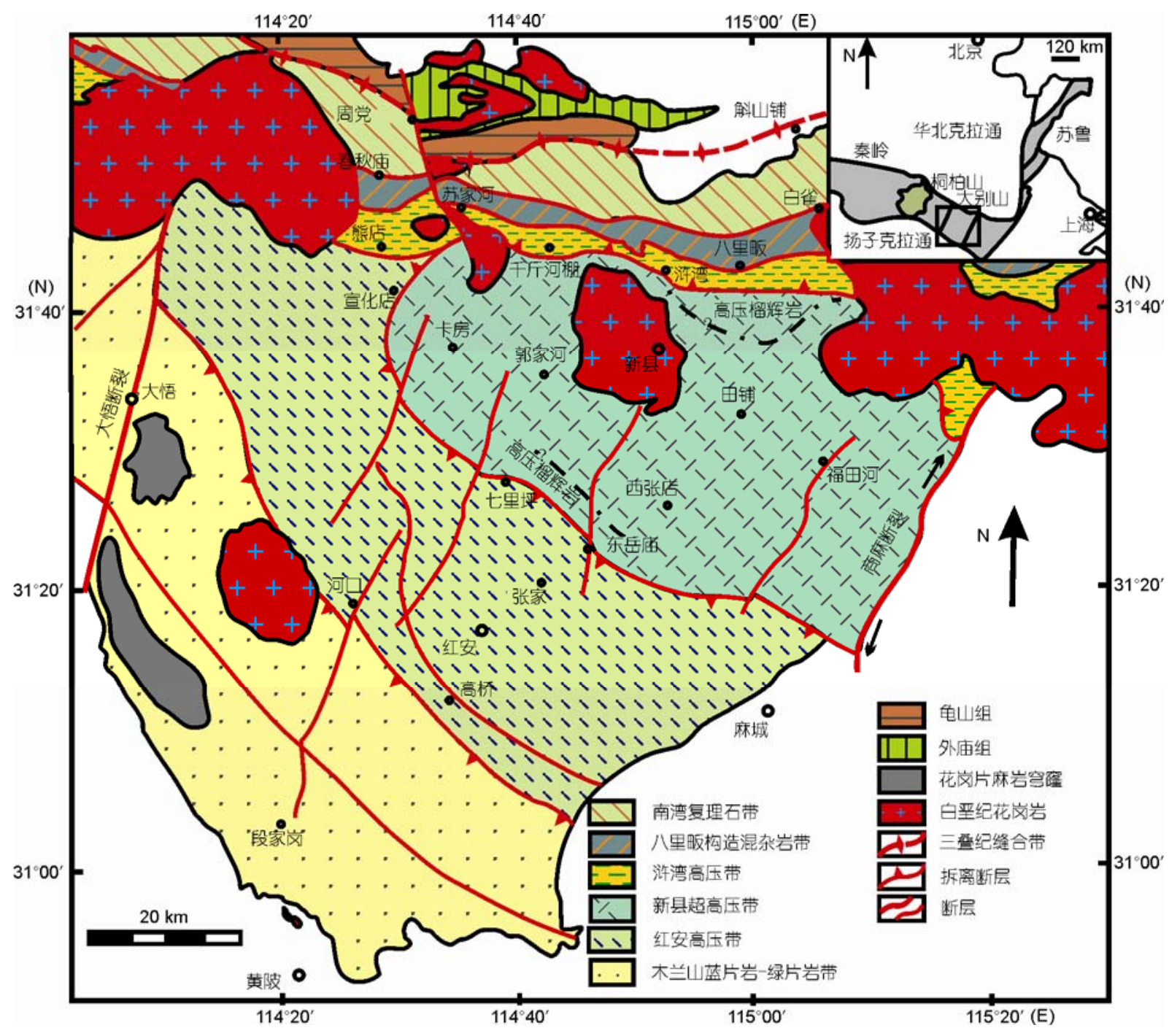

图 1 西大别地区地质构造简图 根据文献[53]修改 
绿片岩对应; (2) 与东部大别和苏鲁造山带相比, 它 受白严纪岩浆活动的热和构造影响非常小; (3) 蓝片 岩-绿片岩相变质岩石在该地区出露最好, 因此是研 究构造变形和变质作用的理想场所.

该地区主要出露的岩石为花岗质片麻岩, 另有 少量的变质表壳岩, 榴辉岩主要以透镜体状产出在 这些岩石中 ${ }^{[55,58 ~ 60]}$. 柯石英及其假相不但出现在新 县超高压变质带的榴辉岩的石榴石和绿辉石中 ${ }^{[55,61]}$, 也出现在该带的区域花岗片麻岩的锆石中, 表明这 些岩石共同经历了超高压变质作用. 近年来, 国内外 地球科学家通过构造、岩石、同位素年代学和地球化 学的综合研究表明, 该地区记录了秦岭-大别-苏鲁造 山带的多期演化历史, 为一典型的复合造山带 [11 13,17,21,34,35,53,57,62 67].

\section{2 西大别榴辉岩的原岩时代和性质}

西大别北部渒湾高压榴辉岩带的峰期变质作用 温压条件为 $530 \sim 730^{\circ} \mathrm{C}$ 和约 $2.0 \mathrm{GPa}$, 角闪岩相退变 质温压条件为 $530 \sim 685^{\circ} \mathrm{C}$ 和约 $0.6 \mathrm{GPa}^{[60,66,67]}$. 这些榴 辉岩与大别-苏鲁造山带广泛出露的高压超高压榴辉 岩具有非常不一致的地球化学特征 64 66]. 其中熊店、 胡家湾和杨冲等地的榴辉岩具有MORB型的微量元 素特点、高的 $\varepsilon_{\mathrm{Nd}}(t)$ 值(高达 6.6)以及高 $\delta^{18} \mathrm{O}$ 值为特征, 表明它们的原岩可能是古特提斯洋壳的一部分 ${ }^{[64 ~ 67]}$. $\mathrm{Li}$ 等人 ${ }^{[64]}$ 还发现胡家湾部分榴辉岩富集大离子亲石 元素、亏损高场强元素且有较低的 $\varepsilon_{\mathrm{Nd}}(t)$ 值, 以及较老 的锆石 $\mathrm{U}-\mathrm{Pb}$ 年龄, 认为它们的原岩可能是晚古生代 的岛弧玄武岩. Fu等人 ${ }^{[66]}$ 对胡家湾的榴辉岩样品进 行系统的地球化学分析后, 发现该地区榴辉岩的 $\varepsilon_{\mathrm{Nd}}(t)$ 值为 $4.9, \delta^{18} \mathrm{O}$ 值为 $8.8 \%$, 微量元素特征与MORB类 似 ${ }^{[66]}$. 而Hacker等人 ${ }^{[47,48]}$ 和Liu等人 ${ }^{[53]}$ 对浒湾高压榴 辉岩带的榴辉岩进行SHRIMP锆石U-Pb定年后, 得到 部分榴辉岩的原岩时代为 $(716 \pm 28) \sim(733 \pm 10) \mathrm{Ma}$ (图 2), 具有富集微量元素和同位素的特征 ${ }^{[62]}$, 属典 型的扬子大陆地壳 ${ }^{[24,30,50]}$. Jahn等人 ${ }^{[62]}$ 根据特征元素 的变化认为熊店榴辉岩存在 $S i$ 的富化, 其高 $\varepsilon_{\mathrm{Nd}}(t)$ 值 可能与这一过程有关, 而并不能反应其原岩具有洋 壳性质.

Wu等人 ${ }^{[21]}$ 对浒湾高压榴辉岩带苏家河和胡家湾 两地的榴辉岩进行LA-(MC)-ICPMS锆石U-Pb定年和 Hf同位素分析结果表明, 这些榴辉岩的原岩形成时 间为 $(406 \pm 5) \sim(420 \pm 7)$ Ma (图 2), 表明这两个地

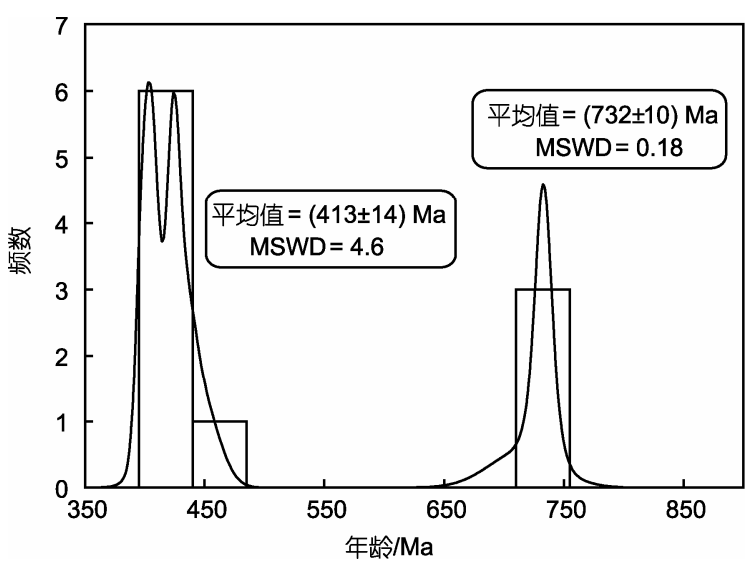

图 2 西大别浒湾地区两类榴辉岩的原岩年龄 数据引自文献[17, 21, 34, 35, 47, 48, 53, 65]

方榴辉岩的原岩时代为志留纪-泥盆纪之间. Cheng等 人 ${ }^{[67]}$ 对熊店榴辉岩进行LA-ICPMS锆石U-Pb定年得 到了类似的结果. 其他研究者对熊店和胡家湾榴辉 岩的研究也得到类似的年龄结果, 但是由于缺乏详 细的成因矿物学的研究, 这些年龄被解释为榴辉岩 相变质锆石的年龄 ${ }^{[34,35,65]}$ 或碎屑锆石的年龄 ${ }^{[17]}$. 部 分榴辉岩中的锆石具有非常高的 $\varepsilon_{\mathrm{Hf}}(t)$ 值和与原岩形 成年龄相近的亏损地幔 Hf模式年龄(图 3), 由于锆石 $\mathrm{Hf}$ 同位素的稳定性, 这样的特征不可能是后期交代 作用形成的, 而只可能指示它们的原岩来自亏损地 幔 ${ }^{[21]}$. 结合已有的Nd-O-H同位素和微量元素研究结 果 ${ }^{[64 ~ 66]}$, 湤湾地区存在晚志留纪的古特提斯洋壳 ${ }^{[21]}$. 部分榴辉岩的锆石给出了较大 $\varepsilon_{\mathrm{Hf}}(t)$ 值和 $\mathrm{Hf}$ 模式年龄 的变化范围, 其中最大的 $\varepsilon_{\mathrm{Hf}}(t)$ 值与亏损地幔值接近, 最小Hf模式年龄与样品的原岩形成年龄相似(图 3), 表明它们的原岩为具有亏损地幔的洋壳, 在其形成 过程中不同程度地混染了地壳物质. Li等人 ${ }^{[64]}$ 报道浒 湾地区部分榴辉岩具有岛弧玄武岩特征的微量元素 组成和较低的 $\varepsilon_{\mathrm{Nd}}(t)$ 值, 可能同样是它们的原岩为洋 壳岩石在其形成过程中混染地壳物质的结果.

因此, 䍊湾地区存在着两种类型原岩性质的榴 辉岩: 古生代大洋地壳和新元古代大陆地壳(图 2). 这两种类型的地壳共存说明, 汻湾地区古生代洋壳 的形成是在扬子板块北缘伸展的基础上发育出来的, 当时汻湾地区可能是一个扬子板块北缘的边缘洋盆.

红安和新县高压-超高压榴辉岩带位于汻湾高压 榴辉岩带的南面, 其中在新县榴辉岩的石榴石和绿 辉石中发现有柯石英及其假相 ${ }^{[55,61]}$, 花岗质片麻岩的 锆石中同样存在有柯石英 ${ }^{[55]}$, 表明该变质带的榴辉岩 

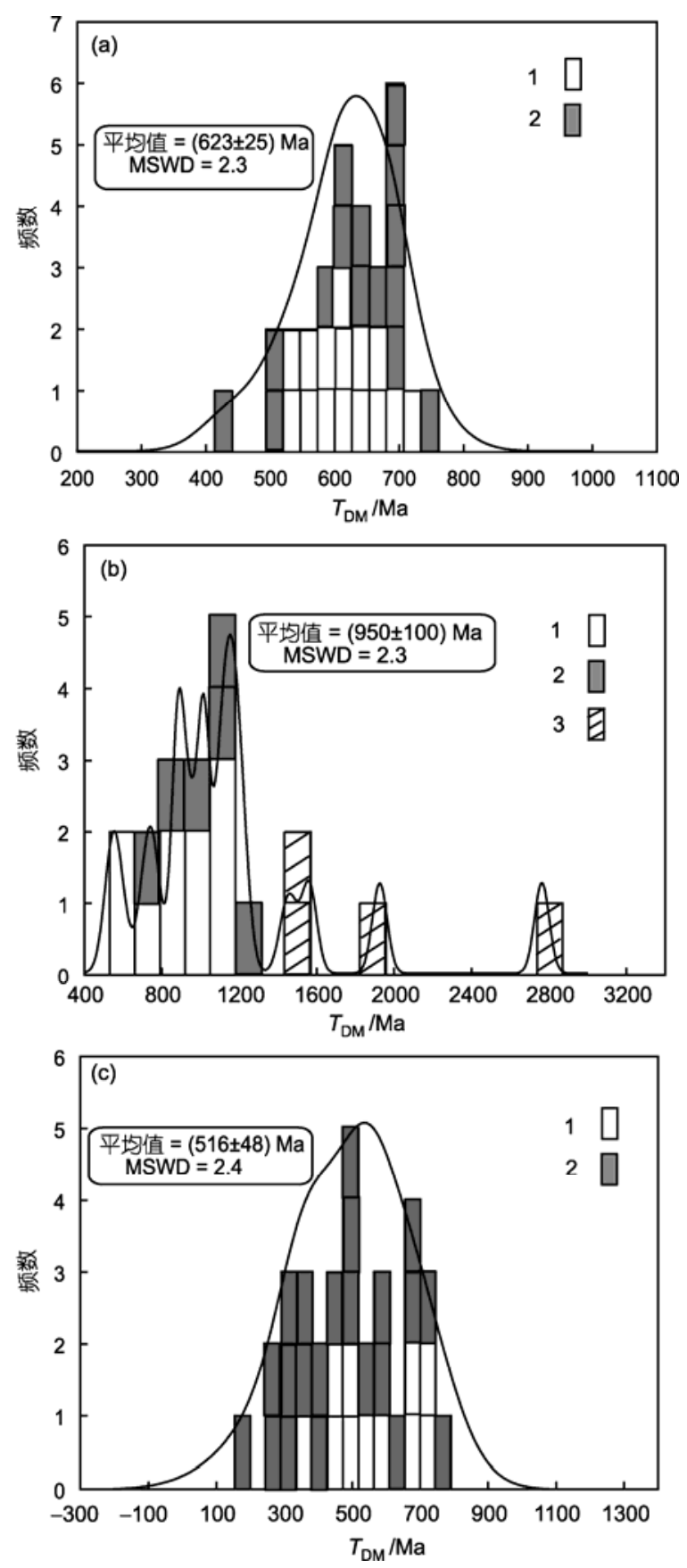

图 3 西大别浒湾地区锆石 Hf 同位素分析结果

根据文献[21]修改. 1, 岩浆锆石区域; 2, 变质锆石区域;

3, 继承锆石区域

和片麻岩共同经历了超高压变质作用. 红安变质带榴 辉岩的峰期变质压力为 $20 \times 10^{6} \sim 22 \times 10^{6} \mathrm{hPa}$, 应属于高 压变质榴辉岩带 ${ }^{[55,58 \sim 60]}$. 锆石微区U-Pb定年结果表明, 这些花岗质片麻岩和榴辉岩的原岩时代为 $(684 \pm 15)$ $(779 \pm 6) \mathrm{Ma} a^{[17,48,53,57]}$ (图 4), 对应于扬子板块周缘大规

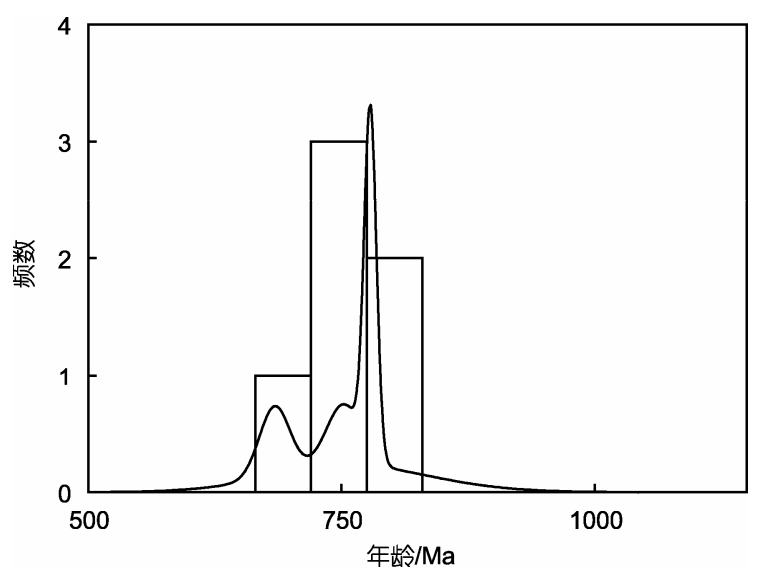

图 4 西大别新县-红安高压-超压榴辉岩带变质岩石的 原岩年龄

数据引自文献[17, 48, 53, 57]

模的新元古代双峰式裂谷岩浆活动 $[48,24,30,50,68 \sim 70]$. Hf同 位素研究结果显示, 榴辉岩和花岗质片麻岩的原岩 形成过程中有明显的亏损地幔物质的加入 ${ }^{[57]}$. 部分 榴辉岩的石榴石和绿辉石的 $\delta^{18} \mathrm{O}$ 值低达 $-8.0 \%{ }^{[62]}$, 与 大别-苏鲁地区大面积出露的 $\delta^{18} \mathrm{O}$ 值变质岩一致, 指 示这些榴辉岩的原岩在形成过程中与低 $\delta^{18} \mathrm{O}$ 值的大 气降水发生了氧同位素交换 ${ }^{[30]}$.

\section{3 石炭纪高压榴辉岩相变质及后期演化}

锆石U-Pb年代学是对高级变质岩石进行定年使 用最广泛的微区定年方法. 但是, 最近的研究表明, 变质锆石可以在俯冲带变质过程中通过生长或重结 晶形成于不同的阶段 [23,24,56,57,71 76]. 这些不确定性限 定了对不同碰撞作用事件发生时间的合理解释和对 古构造格局的重建, 特别是对于像汻湾高压榴辉岩 带这样具有复杂变质演化历史的地区.

简平等人 ${ }^{[34]}$ 首先对该带熊店榴辉岩进行了 IDTIMS法锆石U-Pb定年, 得到锆石的年龄约为 400 和 $300 \mathrm{Ma}$, 这些结果得到了后来SHRIMP分析结果的证 实 ${ }^{[35]}$. 根据同一露头样品的 $\mathrm{Sm}-\mathrm{Nd}$ 和 $\mathrm{Rb}-\mathrm{Sr}$ 年龄结果, 它们将 $(424 \pm 5) \mathrm{Ma}$ 的SHRIMP 锆石U-Pb年龄解释为 该地区榴辉岩相变质的最小年龄, 而把约300 Ma的 年龄看做是后期流体改造作用的时间，由于缺乏系 统的成因矿物学的研究, 这些锆石 $U-\mathrm{Pb}$ 年龄的解释 需要慎重. Xu等人 ${ }^{[77]}$ 对熊店地区的榴辉岩进行了多 硅白云母 ${ }^{40} \mathrm{Ar} /{ }^{39} \mathrm{Ar}$ 定年, 得到350 420 Ma的Ar-Ar坪 年龄和等时年龄, 解释为退变质作用发生的时间, 但 是并不能完全排除高压-超高压变质过程过剩Ar的影 
响 ${ }^{[78]}$. 3 个分别采自熊店和胡家湾的榴辉岩中的变质 锆石通过SHRIMP法给出了(309 \pm 3) Ma的加权平均 ${ }^{206} \mathrm{~Pb} /{ }^{238} \mathrm{U}$ 年龄, 这一年龄结果被解释为榴辉岩相变 质作用的时间 ${ }^{[17]}$. 但是, 这些变质锆石 ${ }^{206} \mathrm{~Pb} /{ }^{238} \mathrm{U}$ 年 龄具有比较大的变化范围, 从约 200 到 $330 \mathrm{Ma}$ (Sun等 人 ${ }^{[17]}$ 中的表 4 和5)和较复杂的稀土元素配分模式，同 时由于熊店和胡家湾与汻湾高压榴辉岩带东部的主 体部分以断层接触(图1), 它们与汻湾高压榴辉岩带 的主体部分的关系不太明确. 因此, 用熊店和胡家湾 榴辉岩的年龄来限定整个浒湾高压榴辉岩带的榴辉 岩相变质作用时间还值得商榷 ${ }^{[53,62]}$. 高山等人 ${ }^{[65]}$ 对熊店榴辉岩进行了 SHRIMP锆石U-Pb年龄测定, 得到 ${ }^{206} \mathrm{~Pb} /{ }^{238} \mathrm{U}$ 年龄分别为 $(449 \pm 14),(307 \pm 14) \mathrm{Ma}$ 和一组 $(216 \pm 4) \mathrm{Ma}(n=6)$ 的结果, 并将后者解释 为这些榴辉岩受到了后期三叠纪变质作用的叠加. Ratschbacher等人 ${ }^{[63]}$ 报道了二叠纪-三叠纪白云母的 ${ }^{40} \mathrm{Ar} /{ }^{39} \mathrm{Ar}$ 坪年龄为约210 270 Ma, 并将它们解释为冷 却过程的年龄. $\mathrm{Wu}$ 等人 ${ }^{[21]}$ 对汻湾高压榴辉岩带东部 的苏家河榴辉岩中的变质锆石进行了详细的U-Pb年 代学、微量元素和Lu-Hf同位素组成分析. 结果发现这 些样品中的变质锆石具有较水平的HREE配分模式、 低 ${ }^{176} \mathrm{Lu} /{ }^{177} \mathrm{Hf}$ 比值以及弱的负 $\mathrm{Eu}$ 异常, 表明这些变质 锆石形成于榴辉岩相变质条件 $[23,24,26,57,71,79 \sim 83]$. 锆石 $\mathrm{Ti}$ 温度计计算结果显示它们的形成温度为 655 和 $638^{\circ} \mathrm{C}$, 与汻湾地区榴辉岩的峰期变质温度条件一致 $[53,60,66]$. 得到(309 \pm 2$) \mathrm{Ma}$ 的年龄, 被认为代表了该地区榴辉 岩相变质作用时间. 㴾湾高压榴辉岩带已有的石炭 纪变质年龄加权平均结果为 $(310 \pm 3) \mathrm{Ma}$ (MSWD = 0.34) (图5), 这一结果表明汻湾地区洋壳榴辉岩发生

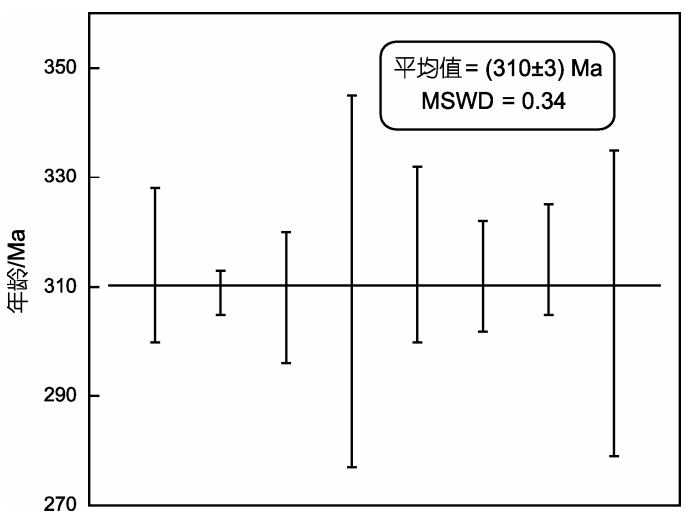

图 5 吘湾高压榴辉岩带石炭纪变质锆石 U-Pb 年龄的 加权平均结果

数据引自文献 $[17,21,34,35,47,48,53,67]$
了石炭纪的榴辉岩相变质作用.

相反, 在汻湾东部的一个样品锆石的核部岩浆 锆石的 ${ }^{206} \mathrm{~Pb} /{ }^{238} \mathrm{U}$ 加权平均年龄为 $(716 \pm 28) \mathrm{Ma}$; 而变 质边给出了 ${ }^{206} \mathrm{~Pb} /{ }^{238} \mathrm{U}$ 年龄从 $(315 \pm 17) \sim(229 \pm 12)$ $\mathrm{Ma}$ 的结果, 最大的年龄被解释为核边混合的结果, 而最年轻的年龄则被看作是该带榴辉岩相变质作用 的最大年龄 [53]. 由于这一年龄不谐和, 且该锆石区域 有明显的多孔结构, 以及高达 $3132 \mathrm{ppm}$ 的U含量. 而 这种类型的锆石在温度为 $120 \sim 200^{\circ} \mathrm{C}$ 的条件下就可 以重置其U-Pb同位素体系 ${ }^{[84]}$, 并且会经历明显的放 射性损伤的影响. 因此, Liu等人 ${ }^{[53]}$ 报道的变质锆石 中最大的更谐和的 $(315 \pm 17) \mathrm{Ma}$ 的年龄应该更接近 该样品榴辉岩相变质作用的年龄, 而三叠纪的年龄 表明它们可能受到了后期三叠纪陆-陆碰撞作用的影 响. 该样品年龄结果反映了汻湾地区的陆壳榴辉岩 同样经历了石炭纪的榴辉岩相变质. Jahn等人 ${ }^{[62]}$ 从该 地区榴辉岩中获得了 210 225 Ma的Rb-Sr单矿物等时 线年龄, 同样可能反映该地区榴辉岩受到了三叠纪 变质作用的影响.

陆壳和洋壳榴辉岩都经历了石炭纪的榴辉岩相 变质作用, 说明这些陆壳榴辉岩和洋壳榴辉岩是作 为一个整体俯冲和抬升的, 洋壳岩石形成于大陆边 缘环境. 其中陆壳岩石由于密度低, 对于洋壳榴辉岩 的出露和保存可能起到了浮力牵引作用. 同样的情 况在Alps高压-超高压变质带也有报道 ${ }^{[83,85]}$.

吘湾地区洋壳俯冲和洋盆闭合的时间在石炭纪 [17,21,60], 而大别-苏鲁造山带主体陆壳的俯冲时间是 三叠纪 $23,24,26,52,55,56]$. 它们是两个比较独立的过程, 还是一个连续的过程, 对于理解洋-陆之间的俯冲转 换过程具有非常重要的意义. 精确确定洋壳的变质 演化历史, 对于这一过程的理解具有非常重要的意 义. Cheng等人 ${ }^{[67]}$ 对汻湾熊店地区的洋壳榴辉岩进行 了详细的石榴石-绿辉石和全岩的Lu-Hf和 Sm-Nd同 位素等时线法定年, 得到较为一致的年龄结果(分别 为 $(271.3 \pm 5.3)$ 和 $(268.9 \pm 6.9) \mathrm{Ma})$. 这一年龄明显晚 于该地区榴辉岩相峰期变质作用年龄 ${ }^{[17,21,67]}$, 结合矿 物学特征和氧同位素分析结果, 这一约 $270 \mathrm{Ma}$ 的年 龄被解释为高压榴辉岩相变质后期和流体存在的条 件下石榴石发生重结晶作用的年龄, 因此是洋壳高 压榴辉岩相变质作用结束的时间, 也是陆壳岩石开 始俯冲时间的最大值 ${ }^{[67]}$. 由于大别-苏鲁造山带陆壳 的起始俯冲时间可能早于约 $245 \mathrm{Ma}^{[26,56,57,67,86,87]}$, 甚 
至早于 $255 \mathrm{Ma}^{[88]}$, 与洋壳高压变质结束的时间仅相 差约 $15 \mathrm{Ma}$, 因此Cheng等人 ${ }^{[67]}$ 认为西大别地区洋壳 和陆壳的俯冲可能是一个连续的过程, 这一过程可 能持续了约 $100 \mathrm{Ma}$ : 洋壳开始俯冲的时间早于 315 $\mathrm{Ma}$ ，峰期变质作用时间约为 $310 \mathrm{Ma}$, 初始折返的时 间为约 $270 \mathrm{Ma}$; 主体陆壳岩石开始俯冲的时间早于 $255 \mathrm{Ma}$ ，到达峰期的时间可能为 240 226 Ma之间， 226 Ma之后为陆壳岩石折返的时间.

\section{4 三叠纪陆壳岩石深俯冲和折返作用}

Eide等人 ${ }^{[59]}$ 对红安和新县高压-超高压岩石进行 Ar-Ar法定年, 得到折返作用阶段的年龄为三叠纪, 可能与大别-苏鲁造山带为一统一的整体. 随后的工 作也支持了他们的结果, 但是得到的年龄变化范围 较大 $(180 \sim 260 \mathrm{Ma}) \stackrel{[17,53,62,69,77,89,90]}{\longrightarrow}$ 这样大的年龄变 化范围很难和大别-苏鲁地区进行对比. 由于该地区 榴辉岩的变质温度较低, 很多石榴石和绿辉石含有 大量的矿物包裹体, Sm-Nd同位素定年没有得到合理 的变质年龄 ${ }^{[62]}$. Sun等人 ${ }^{[17]}$ 最早对该地区的榴辉岩进 行了SHRIMP锆石U-Pb定年, 但是由于测定的锆石具 有非常低的Th和U的含量, 导致测定的年龄结果较为 分散(约 180 260 Ma), 且误差较大. Liu等人 ${ }^{[53]}$ 在田 铺榴辉岩中得到一个 $(213 \pm 5) \mathrm{Ma}$ 的U $-\mathrm{Pb}$ 年龄. $\mathrm{Wu}$ 等 人 ${ }^{[57]}$ 对采自新县超高压变质带四道河的花岗片麻岩 和榴辉岩进行了系统的锆石U-Pb定年, 得到(239 \pm 2$)$ 和 $(227 \pm 2) \mathrm{Ma}$ 两组变质锆石年龄 (图 6), 其

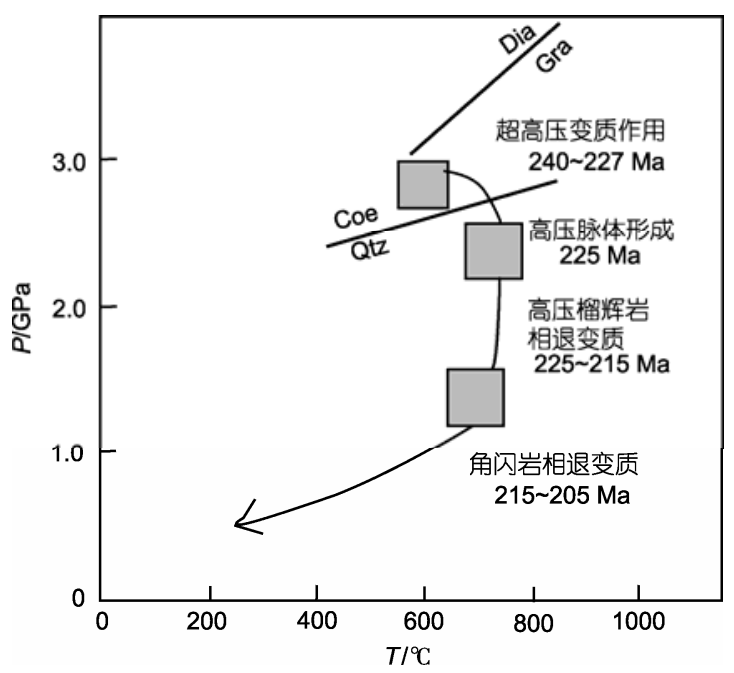

图 6 新县-红安高压-超高压榴辉岩带变质岩石演化的 $P-T-t$ 轨迹

根据文献[74]修改
中(227 \pm 2$) \mathrm{Ma}$ 的锆石具有低的重稀土和低Lu/Hf比 值特征, 表明这些变质锆石形成于超高压-高压的榴 辉岩相抬升阶段, 可能对应于硬柱石等含水矿物的 分解 ${ }^{772]}$ 或名义上无水矿物中结构氢氧羟基在压力降 低条件下的出溶等引起的流体活动 ${ }^{[1,30,91]}$; 而年龄为 $(239 \pm 2) \mathrm{Ma}$ 的锆石具有变化的重稀土元素组成和 $\mathrm{Lu} / \mathrm{Hf}$ 比值, 可能形成于高压-超高压的前进变质作用 阶段, 可能与前进变质过程中钛铁矿和角闪石的分 解导致流体的活动和变质锆石的形成有关 ${ }^{[92,93]}$. 这 些结果与大别山和苏鲁地区的研究结果一致 ${ }^{[23,24,26,52,55,56]}$, 表明红安地区是大别-苏鲁高压超高压 变质带的西延部分 ${ }^{[57]}$.

已有研究表明, 流体活动在高压超高压变质过 程中起到了关键性的作用 230,94 97] . 对大别-苏鲁造山 带大量研究表明, 陆壳岩石在地幔深度的超高压峰 期变质条件下流体活动性很小，但是折返过程中流 体活动性较大 ${ }^{[30,91,96,98,99]}$. Wu等人 ${ }^{[75]}$ 对产于四道河榴 辉岩露头中的一个石英脉样品进行了详细的矿物包 裹体、U-Pb和Hf同位素研究, 对红安地区超高压岩石 抬升过程中流体活动的时间、来源和性质进行了较好 的限定(图 6). 该石英脉中的锆石具有非常规则的外 形和非常低的重稀土和 $\mathrm{Lu} / \mathrm{Hf}$ 比值, 无明显的 $\mathrm{Eu}$ 异常, 主要包裹体为石榴石、绿辉石、金红石、石英和水，表 明锆石是在石英榴辉岩相变质条件下, 从形成石英 脉的流体中结晶形成的. 其(224.7 \pm 1 .3) Ma记录了超 高压岩石折返早期阶段的流体活动的时间, 结合红 安地区已有约 200 215 Ma的锆石U-Pb年龄和多硅白

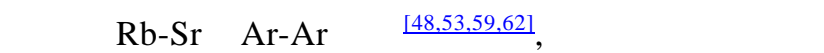
压岩石折返过程中可能经历了两期主要的流体活动 (图 6). 石英脉中锆石的Hf同位素组成与寄主榴辉岩 中锆石的Hf同位素组成较一致, 表明折返早期的流 体主要为内部缓冲流体 ${ }^{[1,30]}$. 锆石包裹体以及石英脉 中有绿辉石的出现, 表明流体为富 $\mathrm{Na}, \mathrm{Si}$ 和 Al的流体. 多硅白云母在石英脉中的沉淀, 表明流体可能富钾, 这与红安地区超高压榴辉岩岩石学的观察结果相吻 合 ${ }^{[55]}$, 折返阶段富钾流体的交代作用在其他高压-超 高压变质地体中也有报道 ${ }^{[100 ~ 102]}$. 石榴石和金红石等 矿物在石英脉和锆石包裹体中出现, 表明超高压岩 石折返早期榴辉岩相变质条件下的流体中HREE和高 场强元素 (如: Zr, Hf, Nb, Ta和Ti等)具有一定的活动 性. 


\section{5 秦岭-大别-苏鲁造山带的多阶段演化}

综合已有的研究结果, 我们可以对扬子和华北 克拉通的碰撞过程进行更加详细的描述(图 7). 对北 秦岭的榴辉岩及相关变质岩的年代学研究结果表明, 华北克拉通和秦岭地体沿商丹缝合带的碰撞发生在 中古生代(ca. 450 500 Ma) ${ }^{[11,38,39,40,41,42,103]}$. 浒湾地区 古特提斯洋壳的形成年龄为约 406 430 $\mathrm{Ma}^{[21]}$, 马昌 前等人 [104]得到南秦岭黄羊山A型花岗岩的SHRIMP 年龄为 $(439 \pm 6) \mathrm{Ma}$, 这些年龄都稍晚于华北和秦岭 的碰撞. 这些年龄结果支持在中古生代华北与秦岭 碰撞后发生了裂谷作用以及随后的晚古生代古特提 斯洋壳的形成, 古特提斯洋可能是形成于扬子板块 北缘的边缘盆地. 这一过程导致了南秦岭和浒湾高 压榴辉岩带从扬子克拉通的裂开 ${ }^{[11,12,21]}$. 古特提斯洋 壳和相连的陆壳基底物质的俯冲代表了另一次事件, 导致了湤湾高压榴辉岩带约(309 \pm 2$) \mathrm{Ma}$ 的榴辉岩相 变质作用 ${ }^{[17,21]}$. 约 $270 \mathrm{Ma}$ 可能是洋-陆俯冲转换的时 间 ${ }^{[68]}$. 南秦岭、桐柏、红安和大别-苏鲁造山带大量 的 220 240 Ma的年龄记录了三叠纪陆陆碰撞作用后

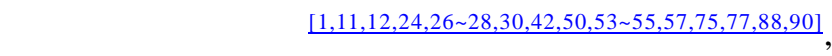
这是另外一次独立的构造事件并且导致了扬子和华

(a) ca. $450 \sim 500 \mathrm{Ma}$

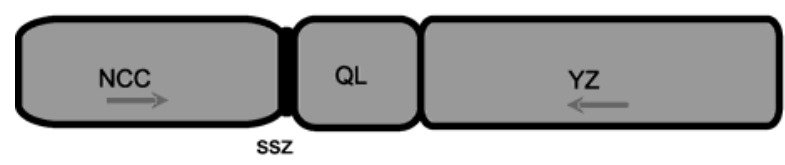

(b) ca. $430 \sim 400 \mathrm{Ma}$

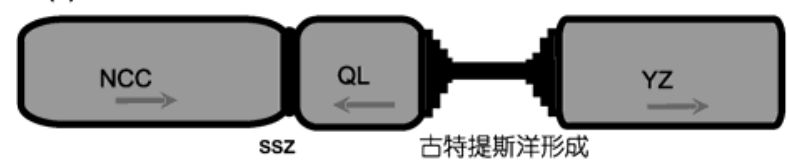

(c) ca. 300 320 Ma

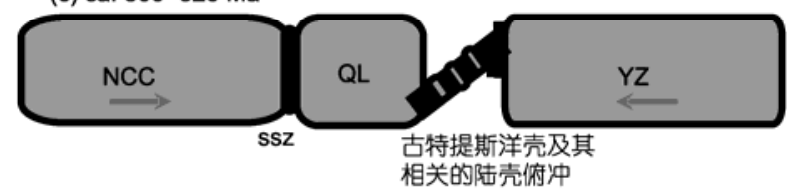

(d) ca. $240 \sim 200 \mathrm{Ma}$

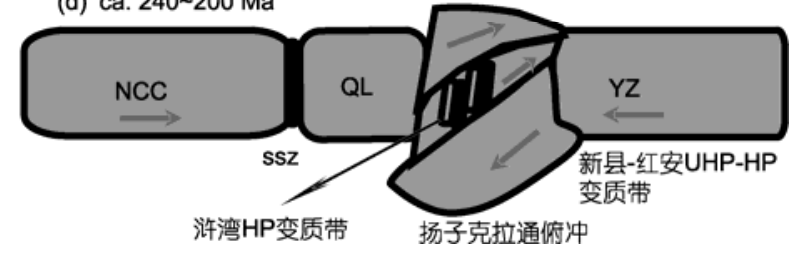

图 7 秦岭-大别-苏鲁造山带的多期演化过程

根据文献[21]修改; NCC, 华北克拉通; QL, 秦岭; YZ, 扬子克拉通; ssz, 商丹缝合带
北克拉通的最终聚合. 因此，扬子和华北的聚合是一 个持续最少 $200 \mathrm{Ma}$ 的多阶段过程.

\section{6 研究展望}

由于对秦岭-大别-苏鲁造山带的研究主要集中 在东大别及苏鲁地区，对于西大别及以西地区的研 还比较薄弱, 要深入了解秦岭-大别-苏鲁造山带的多 期演化历史, 西大别还有以下主要问题还需进一步 明确:

(1) 湤湾地区榴辉岩详细的抬升历史. 浒湾地 区的洋壳榴辉岩和陆壳榴辉岩都给出了约 $310 \mathrm{Ma}$ 的 变质作用年龄 $17,21,34,35,47,48,53,67]$, 洋壳榴辉岩的初始 抬升作用时代约为 $270 \mathrm{Ma}^{[67]}$, 这些洋壳榴辉岩的俯 冲与后期三叠纪大别-苏鲁造山带陆壳俯冲可能是一 个连续的过程 ${ }^{[67]}$. 构造变形作用分析表明西大别是 一个巨大的背斜构造, 其中做湾榴辉岩中存在大量 三叠纪的年龄报道 $[53,62,65]$, 暗示浒湾榴辉岩带转入了 后期的三叠纪变质作用过程之中. 但是由于缺乏这 些高压岩石的详细抬升历史的资料, 这些岩石可能 是在石炭纪俯冲抬升后再经历了后期三叠纪的变质 作用, 即吘湾变质带榴辉岩可能经历了两个阶段的 俯冲作用过程; 亦有可能是洋壳俯冲之后经历了连 续的陆壳的俯冲作用过程 677 . 三叠纪陆壳俯冲作用 对汻湾高压榴辉相变质带的影响程度如何, 也需要 对该变质带的石炭纪榴辉岩相变质样品进行更加深 入的年代学研究工作.

(2) 洋壳榴辉岩的空间展布及洋壳俯冲对应的 岩浆事件. 洋壳榴辉岩的空间展布对于认识西大别 地区古特提斯洋的分布范围有非常重要的意义, 但 是目前的研究仅集中在渒湾地区, 其他地区是否还 有类似时代和性质的洋壳榴辉岩的存在还需进一步 研究; 洋壳的俯冲常常和岛弧岩浆岩对应, 以前的研 究主要集中在变质岩的研究中, 因此以后应加强岩 浆岩的研究确定是否存在同时代岩浆岩作用.

（3）三叠纪陆壳榴辉岩的俯冲和折返时代. Liu 等人臬最近对桐柏地区的高压榴辉岩及其围岩进行 了锆石U-Pb和Ar-Ar, 得到这些高压变质岩石的俯冲 和抬升历史可能稍早于超高压变质岩片, 是高压岩 片与超高压岩片之间拆离解耦和差异折返作用的结 果. 但是, 由于对红安及桐柏地区的高压-超高压岩 石还缺乏深入的多同位素体系的年代学研究, 对于 这些岩石的峰期变质作用和后期抬升过程还缺乏详 
细的了解. 如: 这些岩石的锆石U-Pb年龄约 210 255

区的麻粒岩相变质作用的年龄 ${ }^{[38]}$ 相似, 也与南秦岭 $\mathrm{Ma}^{[17,53,57,75]}$, 它们是记录了这些岩石具有不同峰期 黄羊山A型花岗岩的时代较为一致 ${ }^{[104]}$, 它们反映的 变质作用的年龄, 还是记录了变质岩石前进到后期 可能是同一构造热事件在不同地区产生的不同响应， 抬升各个变质阶段的年龄?

（4）古特提斯洋壳的形成与区域构造演化的关 已有可能是构造演化不同阶段的产物. 需要对这些 系. 浒湾地区古特提斯洋壳的形成年龄 ${ }^{[21]}$ 与桐柏地 地区不同类型的岩石进行准确的年龄测定和同位素 示踪, 来确定它们的地球动力学意义. 意见.

\section{参考文献}

1 郑永飞. 超高压变质与大陆碰撞研究进展: 以大别-苏鲁造山带为例. 科学通报, 2008, 53: 2129-2152

2 Beltrando M, Hermann J, Lister G, et al. On the evolution of orogens: Pressure cycles and deformation mode switches. Earth Planet Sci Lett, 2007, 256: 372-388[doi]

3 England P C, Thompson A B. Pressure-temperature-time paths of regional metamorphism I . Heat transfer during the evolution of regions of thickened continental crust. J Petrol, 1984, 25: 894-928

4 Beaumont C, Ellis S, Hamilton J, et al. Mechanical model for subduction-collision tectonics of Alpine-type compressional orogens. Geology, 1996, 24: 675-678 [doi]

5 Ring U, Brandon M T, Willett S D, et al. Exhumation processes. In: Ring U, Brandon M T, Willett S D, et al, eds. Exhumation Processes: Normal Faulting, Ductile Flow and Erosion. London: Geological Society, 1999, 154: 1-27

6 张国伟，孟庆任，于在平，等。秦岭造山带的造山过程及其动力学特征。中国科学 D 辑: 地球科学, 1996, 26: 193一-200

7 Balanyà J C, Garcia-Duenas V, Azañón J M, et al. Alternating contractional and extensional events in the Alpujarride nappes of the Alboran Domain (Betics, Gibraltar Arc). Tectonics, 1997, 16: 226-238 [1doi]

8 Rawling T J, Lister G. Oscillating modes of orogeny in the Southwest Pacific and the tectonic evolution of New Caledonia. In: Ring U, Brandon M T, Willett S D, et al, eds. Exhumation Processes: Normal Faulting, Ductile Flow and Erosion. London: Geological Society, 1999, 154: 109-127

9 Rubatto D, Gebauer D, Fanning M. Jurassic formation and Eocene subduction of the Zermatt-Saas-Fee ophiolites: Implications for the geodynamic evolution of the Central and Western Alps. Contrib Mineral Petrol, 1998, 132: 269-287[doi]

10 Collins W J. Hot orogens, tectonic switching, and creation of continental crust. Geology, 2002, 30: 535-538[doi]

11 Meng Q R, Zhang G W. Timing of the collision of the North and South China blocks: Controversy and reconciliation. Geology, 1999, 27: $123-126$ [doi]

12 Meng Q R, Zhang G W. Geological framework and tectonic evolution of the Qinling orogen, central China. Tectonophysics, 2000, 323: $183-196[$ doi]

13 Zhai X, Day H W, Hacker B R, et al. Paleozoic metamorphism in the Qinling orogen, Tongbai mountains, central China. Geology, 1998, 26: $371-374$ [doi]

14 Friend C R L, Jones K A, Burns I M. New high-pressure granulite event in the Moine Supergroup, northern Scotland: Implications for Taconic (early Caledonian) crustal evolution. Geology, 2000, 28: 543-546 [doi]

15 Froitzheim N. Origin of the Monte Rosa nappe in the Pennine Alps-A new working hypothesis. Geol Soc Amer Bull, 2001, 113: 604614 [doi]

16 Garcia-Casco A, Torres-Roldan R L, Millan G, et al. Oscillatory zoning in eclogitic garnet and amphibole, Northern Serpentinite Melange, Cuba: A record of tectonic instability during subduction? J Metamorph Geol, 2002, 20: 581-598[doi]

17 Sun W D, Williams I S, Li S G. Carboniferous and Triassic eclogites in the western Dabie Mountains, east-central China: Evidence for protracted convergence of the North and South China Blocks. J Metamorph Geol, 2002, 20: 873-886[doi]

18 Ring U, Layer P W. High-pressure metamorphism in the Aegean, eastern Mediterranean: underplating and exhumation from the Late Cretaceous until Miocene to Recent above the retreating Hellenic subduction zone. Tectonics, 2003, 22: TC1022,[doi]

19 Forster M A, Lister G S. Several distinct tectonometamorphic slices in the Cycladic eclogite-blueschist belt, Greece. Contrib Mineral Petrol, 2005, 150: 525-545

20 Brueckner H K, van Roermund H L M. Concurrent HP metamorphism on both margins of Iapetus: Ordovician ages for eclogites and garnet pyroxenites from the Seve Nappe Complex, Swedish Caledonides. J Geol Soc London, 2007, 164: 117-128 [doi] 
21 Wu Y B, Hanchar J M, Gao S, et al. Age and nature of eclogites in the Huwan shear zone, and the multi-stage evolution of the Qinling-Dabie-Sulu orogen, central China. Earth Planet Sci Lett, 2009, 277: 345-354

22 Schmidberger S S, Heaman L M, Simonetti A, et al. Formation of Paleoproterozoic eclogitic mantle, Slave Province (Canada): Insights from in-situ Hf and U-Pb isotopic analyses of mantle zircons. Earth Planet Sci Lett, 2005, 240: 621-633[doi]

23 Zheng Y F, Wu Y B, Zhao Z F, et al. Metamorphic effect on zircon Lu-Hf and U-Pb isotope systems in ultrahigh-pressure metagranite and metabasite. Earth Planet Sci Lett, 2005, 240: 378-400[ [doi]

24 Zheng Y F, Zhao Z F, Wu Y B, et al. Zircon U-Pb age, Hf and O isotope constraints on protolith origin of ultrahigh-pressure eclogite and gneiss in the Dabie orogen. Chem Geol, 2006, 231: 135-158 [doi]

25 Flowerdew M J, Millar I L, Vaughan A P M, et al. The source of granitic gneisses and migmatites in the Antarctic Peninsula: A combined U-Pb SHRIMP and laser ablation Hf isotope study of complex zircons. Contrib Mineral Petrol, 2006, 151: 751—768[ [doi]

26 Wu Y B, Zheng Y F, Zhao Z F, et al. U-Pb, Hf and O isotope evidence for two episodes of fluid-assisted zircon growth in marble-hosted eclogites from the Dabie orogen. Geochim Cosmochim Acta, 2006, 70: 3743-3761 [doi]

27 Wu Y B, Zheng Y F, Zhang S B, et al. Zircon U-Pb ages and Hf isotope compositions of migmatite from the North Dabie terrane in China: Constraints on partial melting. J Metamorph Geol, 2007, 25: 991-1009 [doi]

28 Liu F L, Gerdes A, Zeng L S, et al. SHRIMP U-Pb dating, trace element and Lu-Hf isotope system of coesite-bearing zircon from amphibolite in SW Sulu UHP terrane, eastern China. Geochim Cosmochim Acta, 2008, 72: 2973 - 3000[doi]

29 Coleman R G, Wang X M. Ultrahigh Pressure Metamorphism. Cambridge: Cambridge University Press, 1995. 1-528

30 Zheng Y F, Fu B, Gong B, et al. Stable isotope geochemistry of ultrahigh pressure metamorphic rocks from the Dabie-Sulu Orogen in China: Implications for geodynamics and fluid regime. Earth Sci Rev, 2003, 62: 105-161 [doi]

31 Liou J G, Tsujimori T, Zhang R Y, et al. Global UHP metamorphism and continent subduction/collision: The Himalayan model. Int Geol Rev, 2004, 46: 1-27 $\underline{\text { [doi] }}$

32 刘贻灿，李曙光. 俯冲陆壳内部的拆离和超高压岩石的多板片差异折返: 以大别-苏鲁造山带为例. 科学通报, 2008, 18: 21532165

33 胡能高, 杨家喜, 赵东林. 北秦岭榴辉岩 Sm-Nd 同位素年龄. 矿物学报, 1996, 16: 349-352

34 简平, 杨巍然, 李志昌, 等. 大别山西部熊店加里东期榴辉岩-同位素年代学的证据. 地质学报, 1997, 71: 133-141

35 简平，刘敦一，杨巍然，等。大别山西部熊店加里东期榴辉岩锆石离子探针测年. 科学通报, 2000, 45: 2090-2093

36 魏春景, 吴玉新, 倪云燕, 等. 河南桐柏地区榴辉岩的特征及其地质意义. 科学通报, 1999, 44: 1882-1885

37 Yang J S, Xu Z Q, Dobrzhinetskaya L F, et al. Discovery of metamorphic diamonds in central China: An indication of a N4000-km-long zone of deep subduction resulting from multiple continental collisions. Terra Nova, 2003, 15: 370-379 [doi]

38 Kröner A, Zhang G, Sun Y. Granulites in the Tongbai area, Qinling belt, China, geochemistry, petrology, single zircon geochronology, and implications for the tectonic evolution of eastern Asia. Tectonics, 1993, 12: 245-255[doi]

39 Gao S, Zhang B R, Gu X M, et al. Silurian-Devonian provenance changes of South Qinling basins: Implications for accretion of the Yangtze (South China) to the North China cratons. Tectonophysics, 1995, 250: 183-197

40 Zhang H F, Gao S, Zhang B R, et al. Pb isotopes of grnitoids suggest Devonian accretion of Yangtze (South China) craton to North China craton. Geology, 1997, 25: 1015-1018[doi]

41 Mattauer M, Matte P, Malavieille J, et al. Tectonics of the Qinling belt: Build-up and evolution of eastern Asia. Nature, 1985, 317: 496-500[doi]

42 Zhai X, Day H W, Hacker B R, et al. Paleozoic metamorphism in the Qinling orogen, Tongbai mountains, central China. Geology, 1998, 26: 371 -374[doi]

43 杨经绥, 许志琴, 裴先治, 等. 秦岭发现金刚石: 横贯中国中部巨型超高压变质带新证据及古生代和中生代两期深俯冲作用的识别. 地质学报, 2002, 76: 484-495

44 Li S G, Xiao Y L, Liu D L, et al. Collision of the North China and Yangtze Blocks and formation of coesite-bearing eclogites: Timing and processes. Chem Geol, 1993, 109: 89-111 [1doi]

45 Li S G, Jagoutz E, Chen Y Z, et al. Sm-Nd and Rb-Sr isotopic chronology and cooling history of ultrahigh pressure metamorphic rocks and their country rocks at Shuanghe in the Dabie Mountains, Central China. Geochim Cosmochim Acta, 2000, 64: 1077-1093[doi]

46 Ames L, Zhou G Z, Xiong B C. Geochronology and isotopic character of ultrahigh-pressure metamorphism with implications for collision of the Sino-Korean and Yangtze cratons, central China. Tectonics, 1996, 15: 472-489 [doi]

47 Hacker B R, Ratschbacher L, Webb L, et al. U/Pb zircon ages constrain the architecture of the ultrahigh-pressure Qinling-Dabie Orogen, China. Earth Planet Sci Lett, 1998, 161: 215-230[doi]

48 Hacker B R, Ratschbacher L, Webb L, et al. Exhumation of ultrahigh-pressure continental crust in east central China: Late Triassic-Early Jurassic tectonic unroofing. J Geophys Res, 2000, 105: 13339-13364 [doi]

49 Ayers J C, Dunkle S, Gao S, et al. Constraints on timing of peak and retrograde metamorphism in the Dabie Shan Ultrahigh-Pressure Metamorphic Belt, east-central China, using U-Th-Pb dating of zircon and monazite. Chem Geol, 2002, 186: 315-331 [doi]

50 Zheng Y F, Wu Y B, Chen F K, et al. Zircon U-Pb and oxygen isotope evidence for a large-scale ${ }^{18} \mathrm{O}$ depletion event in igneous rocks during the Neoproterozoic. Geochim Cosmochim Acta, 2004, 68: 4145-4165[doi] 
51 Liu F L, Xu Z Q, Liou J G, et al. SHRIMP U-Pb ages of ultrahigh-pressure and retrograde metamorphism of gneisses, southwest Sulu terrane, eastern China. J Metamorph Geol, 2004, 22: 315-326 [doi]

52 Liu F L, Xu Z Q, Xue H M. Tracing the protolith, UHP metamorphism, and exhumation ages of orthogneiss from the SW Sulu terrane (eastern China): SHRIMP U-Pb dating of mineral inclusion bearing zircons. Lithos, 2004, 78: 411-429 [doi]

53 Liu X C, Jahn B M, Liu D Y, et al. SHRIMP U-Pb zircon dating of a metagabbro and eclogites from western Dabieshan (Hong'an Block), China, and its tectonic implications. Tectonophysics, 2004, 394: 171-192[doi]

54 Liu D Y, Jian P, Kröner A, et al. Dating of prograde metamorphic events deciphered from episodic zircon growth in rocks of the Dabie-Sulu UHP complex, China. Earth Planet Sci Lett, 2006, 250: 650-666[doi]

55 Liu J B, Ye K, Sun M. Exhumation P-T path of UHP eclogites in the Hong'an area, western Dabie Mountains, China. Lithos, 2006, 89: 154-173[doi]

56 Wan Y S, Li R W, Wilde S A, et al. UHP metamorphism and exhumation of the Dabie Orogen, China: Evidence from SHRIMP dating of zircon and monazite from a UHP granitic gneiss cobble from the Hefei Basin. Geochim Cosmochim Acta, 2005, 69: 4333-4348[doi]

57 Wu Y B, Gao S, Zhang H F, et al. Timing of UHP metamorphism in the Hong’an area, western Dabie Mountains, China: Evidence from zircon U-Pb age, trace element and Hf isotope composition. Contrib Mineral Petrol, 2008, 155: 123 - 133[doi]

58 Zhong Z Q, Suo S T, You Z D. Regional-scale extensional tectonic pattern of ultrahigh-P and high-P metamorphic belts from the Dabie massif, China. Int Geol Rev, 1999, 41: 1033-1041 [doi]

59 Eide E A, Liou J G. High-pressure blueschists and eclogites in Hong'an: A framework for addressing the evolution of high- and ultrahigh-pressure rocks in central China. Lithos, 2000, 52: 1-22[doi]

60 Liu X C, Wei C J, Li S Z, et al. Thermobaric structure of a traverse across western Dabieshan: Implications for collision tectonics between the Sino-Korean and Yangtze cratons. J Metamorph Geol, 2004, 22: 361-379 [doi]

61 Liu J B, Ye K. Transformation of garnet epidote amphibolite to eclogite, western Dabie Mountains, China. J Metamorph Geol, 2004, 22: $383-394$ [doi]

62 Jahn B M, Liu X C, Yui T F, et al. High-pressure/ultrahigh-pressure eclogites from the Hong'an Block, East-Central China: Geochemical characterization, isotope disequilibrium and geochronological controversy. Contrib Mineral Petrol, 2005, 149: 499-526 [doi]

63 Ratschbacher L, Franz L, Enkelmann E, et al. The Sino-Korean-Yangtze suture, Huwan detachment, and Paleozoic-Tertiary exhumation of (ultra)high-pressure rocks in Tongbai-Xinxian-Dabie. In: Hacker B R, McClelland W C, Liou J G. eds. Ultrahigh-Pressure Metamorphism: Deep Continental Subduction. Geol Soc Am, 2006, 403: 45-76

64 Li S G, Huang F, Nie Y H, et al. Geochemical and geochronological constraints on the suture location between the North and South China blocks in the Dabie Orogen, Central China. Phys Chem Earth Part A: Solid Earth Geod, 2001, 26: 655-672k [doi]

65 高山, Qiu Y M, 凌文黎, 等. 大别山英山和熊店榴辉岩单颗粒锆石 SHRIMP U-Pb 年代学研究. 地球科学, 2002, 27: 558- 564

66 Fu B, Zheng Y F, Touret J L R. Petrological, isotopic and fluid inclusion studies of eclogites from Sujiahe, NW Dabie Shan (China). Chem Geol, 2002, 187: 107-128 [doi]

67 Cheng H, King R L, Nakamura E, et al. Transitional time of oceanic to continental subduction in the Dabie orogen: constraints from U-Pb, Lu-Hf, Sm-Nd and Ar-Ar multichronometric dating. Lithos, 2009, [doi]

68 Li X H, Li Z X, Ge W C, et al. Neoproterozoic granitoids in South China: Crustal melting above a mantle plume at ca. 825 Ma? Precambrian Res, 2003, 122: 45-83 $\underline{\text { [doi] }}$

69 Wu Y B, Zheng Y F, Zhou J B. Neoproterozoic granitoid in northwest Sulu and its bearing on the North China-South China Blocks boundary in east China. Geophys Res Lett, 2004, 31: L07616, [doi]

$70 \mathrm{Wu} \mathrm{Y} \mathrm{B,} \mathrm{Zheng} \mathrm{Y} \mathrm{F,} \mathrm{Tang} \mathrm{J,} \mathrm{et} \mathrm{al.} \mathrm{Zircon} \mathrm{U-Pb} \mathrm{dating} \mathrm{of} \mathrm{water-rock} \mathrm{interaction} \mathrm{during} \mathrm{Neoproterozoic} \mathrm{rift} \mathrm{magmatism} \mathrm{in} \mathrm{South} \mathrm{China.}$ Chem Geol, 2007, 246: 65-86[doi]

71 吴元保, 郑永飞. 锆石成因矿物学研究及其对 U-Pb 年龄解释的制约. 科学通报, 2004, 49: 1589-1604

72 Rubatto D, Gebauer G, Compagnoni R. Dating of eclogitefacies zircons: the age of Alpine metamorphism in the Sesia-Lanzo Zone (Western Alps). Earth Planet Sci Lett, 1999, 167: 141-158[doi]

73 Liati A, Gebauer D. Constraining the prograde and retrograde P-T-t path of Eocene HP rocks by SHRIMP dating difference zircon domain: inferred rated of heating-burial, cooling and exhumation for central Rhodope, northern Greece. Contrib Mineral Petrol, 1999, 135: $340-354$ [doi]

74 Li X P, Zheng Y F, Wu Y B, et al. Low-T eclogite in the Dabie terrane of China: petrological and isotopic constraints on fluid activity and radiometric dating. Contrib Mineral Petrol, 2004, 148: 443-470

$75 \mathrm{Wu} \mathrm{Y} \mathrm{B,} \mathrm{Gao} \mathrm{S,} \mathrm{Zhang} \mathrm{H} \mathrm{F,} \mathrm{et} \mathrm{al.} \mathrm{U-Pb} \mathrm{age,} \mathrm{trace-element,} \mathrm{and} \mathrm{Hf-isotope} \mathrm{composition} \mathrm{of} \mathrm{zircons} \mathrm{in} \mathrm{a} \mathrm{quartz} \mathrm{vein} \mathrm{from} \mathrm{eclogite} \mathrm{in} \mathrm{the}$ western Dabie Mountains: Constraints on fluid flow during early exhumation of ultra-high pressure rock. Am Mineral, 2009, 94: 303312 [doi]

$76 \mathrm{Wu}$ Y B, Zheng Y F, Gao S, et al. Zircon U-Pb age and trace element evidence for Paleoproterozoic granulite-facies metamorphism and Archean crustal rocks in the Dabie Orogen. Lithos, 2008, 101: 308 - 322[doi]

$77 \mathrm{Xu} \mathrm{B}$, Grove M, Wang C, et al. ${ }^{40} \mathrm{Ar} /{ }^{39} \mathrm{Ar}$ thermochronology from the northwestern Dabie Shan: constraints on the evolution of Qinling-Dabie orogenic belt, east-central China. Tectonophysics, 2000, 322: 279-301 [doi] 
78 Li S G, Wang S S, Chen Y Z, et al. Excess argon in phengite from eclogite-evidence from dating of eclogite minerals by Sm-Nd, Rb-Sr and ${ }^{40} \mathrm{Ar} /{ }^{39} \mathrm{Ar}$ methods. Chem Geol, 1994, 112: 343-350[doi]

79 Hermann J, Rubatto D, Korsakov A. Multiple zircon growth during fast exhumation of diamondiferous, deeply subducted continental crust (Kokchetav Massif, Kazakhstan). Contrib Mineral Petrol, 2001, 141: 66-82

80 Rubatto D. Zircon trace element geochemistry: partitioning with garnet and the link between U-Pb ages and metamorphism. Chem Geol, 2002, 184: 123 - 138 [doi]

81 Rubatto D, Hermann J. Zircon formation during fluid circulation in eclogites (Monviso, Western Alps): Implications for Zr and Hf budget in subduction zones. Geochim Cosmochim Acta, 2003, 67: 2173-2187 [doi]

82 Rubatto D, Hermann J. Experimental zircon/melt and zircon/garnet trace element partitioning and implications for the geochronology of crustal rocks. Chem Geol, 2007, 241: 38-61[doi]

83 Giacomini F, Braga R, Tiepolo M, et al. New constraints on the origin and age of Variscan eclogitic rocks (Ligurian Alps, Italy). Contrib Mineral Petrol, 2007, 153: 29-53[ [doi]

84 Geisler T, Rashwan A A, Rahn M K W, et al. Low temperature hydrothermal alteration of natural metamict zircons from the Eastern Desert, Egypt. Mineral Mag, 2003, 67: 485-508[doi]

85 Lapen T J, Johnson C M, Baumgartner L P, et al. Coupling of oceanic and continental crust during Eocene eclogite-facies metamorphism: Evidence from the Monte Rosa nappe, western Alps. Contrib Mineral Petrol, 2007, 153: 139-157 [doi]

86 Liu F L, Gerdes A, Liou J G, et al. SHRIMP U-Pb zircon dating from Sulu-Dabie dolomitic marble, eastern China: Constraints on prograde, ultrahigh-pressure and retrograde metamorphic ages. J Metamorph Geol, 2006, 24: 569-589

87 Xu Z Q, Zeng L S, Liu F L, et al. Polyphase subduction and exhumation of the Sulu high-pressure-ultrahigh-pressure metamorphic terrane. Geol Soc Am Spec Paper, 2006, 403: 93-113

88 Liu X C, Jahn B M, Dong S W, et al. High-pressure metamorphic rocks from Tongbaishan, central China: U-Pb and ${ }^{40} \mathrm{Ar} /{ }^{39} \mathrm{Ar}$ age constraints on the provenance of protoliths and timing of metamorphism. Lithos, 2008, 105: 301-318 [doi]

89 Zhong Z Q, Suo S T, You Z D, et al. Major constituents of the Dabie collisional orogenic belt and partial melting in the ultrahigh- pressure unit. Int Geol Rev, 2001, 43: 226-236 [doi]

90 Webb L E, Hacker B R, Ratschbacher L, et al. Thermochronologic constraints on deformation and cooling history of high- and ultrahigh-pressure rocks in the Qinling-Dabie orogen, eastern China. Tectonics, 1999, 18: 621-638[doi]

91 Chen R X, Zheng Y F, Gong B, et al. Origin of retrograde fluid in ultrahigh-pressure metamorphic rocks: constraints from mineral hydrogen isotope and water content changes in eclogite-gneiss transitions in the Sulu orogen. Geochim Cosmochim Acta, 2007, 71: 2299-2325[doi]

92 Bingen B, Austrheim H, Whitehouse M J. Ilmenite as a source for zirconium during high-grade metamorphism? Textural evidence from the Caledonides of Western Norway and implications for zircon geochronology. J Petrol, 2001, 42: 355-375

93 Bingen B, Austrheim $\mathrm{H}$, Whitehouse M J, et al. Trace element signature and U-Pb geochronology of eclogite-facies zircon, Bergen Arcs, Caledonides of W Norway. Contrib Mineral Petrol, 2004, 147: 671-683

94 Agard P, Goffé B, Touret J L R, et al. Retrograde mineral and fluid evolution in highpressure metapelites (Schistes lustrés unit, Western Alps). Contrib Mineral Petrol, 2000, 140: 296-315[ [doi]

95 Miller J A, Buick I S, Cartwright I, et al. Fluid processes during the exhumation of high-P metamorphic belts. Mineral Mag, 2002, 66: 93-119 [doi]

96 Zheng Y F, Wu Y B, Gong B, et al. Tectonic driving of Neoproterozoic glaciations: Evidence from extreme oxygen isotope signature of meteoric water in granite. Earth Planet Sci Lett, 2007, 256: 196 - 210[doi]

97 Hermann J, Spandler C, Hack A, et al. Aqueous fluids and hydrous melts in high-pressure and ultrahigh pressure rocks: Implications for element transfer in subduction zones. Lithos, 2006, 92: 399-417 [doi]

98 Rumble D, Wang Q C, Zhang R Y. Stable isotope geochemistry of marbles from the coesite UHP terrains of Dabieshan and Sulu, China. Lithos, 2000, 52: 79-95[doi]

99 Fu B, Touret J L R, Zheng Y F. Fluid inclusions in coesite-bearing eclogites and jadeite quartzite at Shuanghe, Dabie Shan, China. J Metamorph Geol, 2001, 19: 529-545

100 Molina J F, Austrheim H, Glodny J, et al. The eclogites of the Marun-Keu complex, Polar Urals (Russia): Fluid control on reaction kinetics and metasomatism during high P metamorphism. Lithos, 2002, 61: 55-78 [doi]

101 Schulte B, Sindern S. K-rich fluid metasomatism at highpressure metamorphic conditions: Lawsonite decomposition in rodingitized ultramafite of the Maksyutovo Complex, southern Urals (Russia). J Metamorph Geol, 2002, 20: 529—541 [doi]

102 Keller L M, Abart R, Stunitz H, et al. Deformation, mass transfer and mineral reactions in an eclogite facies shear zone in a polymetamorphic metapelite (Monte Rosa nappe, western Alps). J Metamorph Geol, 2004, 22: 97-118 $\underline{\text { [doi] }}$

103 Yang J S, Liu F L, Wu C L, et al. Two ultrahigh-pressure metamorphic events recognized in the central orogenic belt of China: Evidence from the U-Pb dating of coesite-bearing zircons. Int Geol Rev, 2005, 47: 323-343

104 马昌前, 余振兵, 许聘, 等. 桐柏-大别山南缘的志留纪 A 型花岗岩类: SHRIMP 锆石年代学和地球化学证据. 中国科学 D 辑: 地球科学, 2004, 34: 1100-1110 